\title{
PENGEMBANGAN PERANGKAT PEMBELAJARAN IPA BERKARAKTER BERBASIS INTEGRASI MODEL PEMBELAJARAN PROBLEM BASED LEARNING DAN KETERAMPILAN PROSES SAINS
}

\author{
Arman ${ }^{1 *}$, Muhsinah Annisa ${ }^{2}$, Kartini $^{3}$ \\ Pendidikan guru sekolah dasar Universitas Borneo Tarakan \\ *corresponding Author: armanpardi07@gmail.com
}

DOI: $10.24929 /$ lensa.v10i1.90

Received: 6 Maret 2020

Revised: 16 April 2020

Accepted: 18 Mei 2020

\begin{abstract}
ABSTRAK
Penelitian ini bertujuan untuk mendeskripsikan kelayakan perangkat pembelajaran IPA berkarakter berbasis integrasi model pembelajaran problem based learning dan keterampilan proses sains ditinjau dari uji validasi isi, konstruk, dan bahasa serta respon siswa. Prosedur pengembangan perangkat pembelajaran yang digunakan pada model pengembangan 3-D, yaitu Define, Design, Develop. Perangkat pembelajaran yang dikembangkan adalah silabus dan RPP, Buku Ajar Siswa (BAS) dan Lembar kerja siswa (LKS). Teknik pengumpulan data yang digunakan adalah wawancara, observasi, tes, kuesioner atau angket dan dokumentasi. Kelayakan perangkat pembelajaran yang dikembangkan memenuhi kriteria sangat layak berdasarkan skor rata-rata oleh tim ahli. Berdasarkan penelitian, dapat disimpulkanbahwa perangkat pembelajaran yang dikembangkan dapat disimpulkan bahwa perangkat pembelajaran yang dikembangkan sangat layak ditinjau dari hasil validasi isi, konstruk dan bahasa serta respon siswa sangat baik.
\end{abstract}

Kata Kunci: Pengembangan perangkat pembelajaran, IPA, Karakter, Problem based learning , Keterampilan proses sains

\section{PENDAHULUAN}

Ilmu Pengetahuan Alam atau IPA merupakan suatu ilmu pengetahuan yang diperoleh karena proses ilmiah dan sikap ilmiah, dimana aktivitas tersebut berasal dari pemikiran manusia yang menghasilkan sebuah produk ilmiah (Annisa, Yulinda, \& Kartini, 2017). Pembelajaran merupakan segala sesuatu yang dapat membawa informasi dan pengetahuan dalam interaksi yang berlangsung antara pendidik dengan siswa (Dewi, 2018). Pembelajaran yang baik diharapkan dapat membuat karakter siswa dapat mengembangkan rasa ingin tahu, dan sikap positif lainnya. Hal ini sejalan dengan tujuan mata pelajaran ilmu pengetahuan alam (IPA) di Sekolah Dasar dari segi pendidikan karakter salah satunya yaitu siswa dapat mengembangkan rasa ingin tahu, sikap yang positif dan kesadaran mengenai hubungan yang saling mempengaruhi antara IPA, teknologi, dan masyarakat, dan siswa dapat mengembangkan keterampilan proses untuk mengamati alam sekitar. Tercapainya tujuan pembelajaran IPA tersebut sangat ditentukan dengan pendidikan karakter dan keterampilan proses sains yang dimiliki oleh siswa dalam menunjang kualitas pembelajaran. Keterampilan proses sains sangat membantu dalam mencapai tujuan pembelajaran IPA. Namun ada juga sekolah yang belum menerapkan keterampilan proses sains dalam setiap mata pelajaran IPA. Hal ini sesuai dengan pernyataan Annisa dkk (2017) menjelaskan bahwa guru sangat sedikit mengetahui tentang keterampilan proses sains dalam pembelajaran. 
Hal ini diperkuat dengan hasil observasi proses pembelajaran yang berlangsung di dalam kelas dan wawancara melalui guru kelas. Guru dalam melaksanakan pembelajaran masih bersifat tradisional atau konvensional. Guru pernah membuat perangkat pembelajaran sebelum melaksanakan pembelajaran di kelas, namun hanya silabus dan rencana pelaksanaan pembelajaran (RPP) karena adanya faktor penghambat yaitu kemampuan dalam mengoperasikan komputer serta pemahaman tentang perangkat pembelajaran yang masih sangat kurang. Guru belum menerapkan model pembelajaran seperti model pembelajaran problem based learning. Guru belum memahami penjelasan dari model pembelajaran, guru masih cenderung menggunakan metode ceramah dalam pembelajaran IPA, Guru juga belum pernah menerapkan keterampilan proses sains dalam pembelajaran. Siswa belum mampu melakukan kegiatan yang terkait dengan pemecahan masalah. Siswa mengalami kesulitan dalam memahami materi yang disampaikan oleh guru. Kegiatan pembelajaran yang dilakukan belum menerapkan nilai karakter, seperti nilai karakter rasa ingin tahu dan tanggung jawab.

Belajar tidak hanya menuntut penguasaan fakta, konsep dan generalisasi, tetapi menampilkan pesan nilai moral yang terkandung dalam pengetahuan itu (Bhakti, 2018). Pembelajaran ilmiah membutuhkan suatu proses yang dapat merangsang siswa untuk belajar melalui berbagai masalah nyata di kehidupan sehari-hari (Serevina, 2018). Pembelajaran IPA juga diharapkan dapat menjadi tempat bagi peserta didik untuk mempelajari dan memahami diri sendiri dan alam sekitar, serta pengembangan lebih lanjut dalam menerapkanya di dalam kehidupan sehari-hari (Saputri, 2018)

Pembelajaran ilmu pengetahuan alam (IPA) yang sejalan dengan pendidikan karakter sangat penting dalam menunjang tujuan pembelajaran maka untuk itu diperlukan model dan pendekatan pembelajaran yang menunjang terlaksananya proses pembelajaran di sekolah, salah satunya adalah integrasi model pembelajaran problem based learning dan keterampilan prores sains. Keterampilan proses dapat melatih siswa untuk berpikir secara ilmiah dan kerja sistematis (Haniah, 2018). Persamaan model pembelajaran problem based learning dengan keterampilan proses sains pembelajaran adalah menyelesaikan masalah melalui tahapan pengamatan dan penyimpulan. Berdasarkan persamaan tersebut maka pendidikan nilai karakter dapat tercapai melalui aspek rasa ingin tahu dan tanggung jawab. Rasa ingin tahu yaitu siswa mencari tahu tentang bagaimana memecahkan suatu masalah, nilai karakter tanggung jawab yaitu sikap atau perilaku siswa dalam meyeleasikan tugas yang diberikan dengan baik.

Pengembangan perangkat pembelajaran IPA berkarakter berbasis integrasi model pembelajaran problem based learning dan keterampilan proses sains dapat menjadi salah satu penunjang perencanaan pembelajaran di sekolah agar siswa dapat mengembangkan keterampilan proses untuk mengamati alam sekitar sesuai dengan tujuan pembelajaran IPA di sekolah. Penelitian pengembangan perangkat pembelajaran berbasis keterampilan proses sains juga telah dilakukan oleh Azhari (2018) yang mengembangkan perangkat pebelajaran berbasis cooperatif script dan keterampilan proses sains. Hasil yang diperroleh yaitu perangkat pembelajaran yang dikembangkan mendapatkan skor rata-rata 3.31 dengan kriteria sangat baik dan respon siswa mendapatkan kriteria sangat baik, akan tetapi belum ada pengembangan perangkat pembelajaran IPA yang memuat karakter dan berbasis integrase model problem based learning dan keterampilan proses sains. Berbagai pengembangan perangkat pembelajaran dapat membuat guru melakukan perencanaan pembelajaran lebih baik, dan masing-masing perangkat pembelajaran saling melengkapi satu sama lain.

Berdasarkan uraian tersebut, maka peneliti ingin mendeskripsikan kelayakan perangkat pembelajaran IPA berkarakter berbasis integrasi model pembelajaran problem based learning dan keterampilan proses sains ditinjau dari uji validasi isi, konstruk, Bahasa, keterlaksanaan dan serta respon siswa terhadap pembelajaran. 


\section{METODE PENELITIAN}

Jenis penelitian dan pengembangan yang dilakukan oleh peneliti mengacu pada langkah research and development $(R \& D)$ dengan produk yang dikembangkan silabus, rencan pelaksanaan pembelajaran (RPP,) buku ajar siswa (BAS) dan lembar kerja siswa (LKS). Model pengembangan yang digunakan pada penelitian ini adalah model pengembangan 4D, yang meliputi tahap define (pendefinisian), design (perancangan), develop (pengembangan), dan disseminate (penyebaran), namun pada penelitian ini peneliti hanya menggunakan sampai tahap develop karena keterbatasan waktu dan biaya

Penelitian ini menggunakan penelitian dan pengembangan atau research and development $(R \& D)$. Produk yang dikembangkan adalah pengembangan perangkat pembelajaran IPA berkarakter berbasis integrasi model pembelajaran problem based learning dan keterampilan proses sains di kelas $\mathrm{V}-\mathrm{C}$. Model pengembangan yang digunakan adalah model 4-D, namun hanya sampai tahap 3-D karena keterbatasan biaya dan waktu. Prosedur Penelitian dan Pengembangan adalah sebagai berikut.

1. Tahap Pendefinisian (define)

Tahapan ini dilakukan bertujuan untuk menetapkan dan mendefinisikan kebutuhan dalam proses pengembangan. Menurut Ibrahim dalam Sulistyorini (2016: 196) terdapat 5 langkah pokok di dalam tahap ini, yaitu:

a. Analisis ujung depan

Pada tahap ini, peneliti melakukan diagnosis awal yaitu observasi proses pembelajaran yang berlangsung di dalam kelas dan wawancara melalui guru kelas V-C SDN 049 Tarakan.

b. Analisis siswa

Pada tahap ini peneliti melakukan analisis karakteristik siswa, kemampuan siswa dan pengalaman siswa dalam pembelajaran.

c. Analisis tugas

Pada tahapan ini peneliti menganalisis tugas pokok yang harus dikuasai siswa, sehingga siswa dapat mencapai tujuan pembelajaran, mencakup struktur isi dan prosedur dalam mengerjakan lembar kerja siswa (LKS) dan tes hasil belajar (THB).

d. Analisis konsep

Menganalisis konsep perubahan sifat benda yang di sebabkan oleh pembakaran, pemanasan, perkaratan, pendinginan, dan pembusukan serta dapat bersifat sementara dan tetap yang diajarkan kepada siswa.

e. Menentukan tujuan pembelajaran

Peneliti merumuskan tujuan pembelajaran, perubahan perilaku yang diharapkan setelah belajar dengan menggunakan rumusan ABCD (Audience, Behavior, Condition and Degree).

2. Tahap Perancangan (Design)

Menurut Thiagarajan dalam Hanum (2015: 24) tahap Design terbagi menjadi empat kegiatan, yaitu: menyusun tes, memilih media, memilih bentuk penyajian dan desain perangkat pembelajaran. Berdasarkan definisi tersebut, kegiatan dapat dijelaskan sebagai berikut:

a. Menyusun tes yang disesuaikan dengan indikator dan tujuan pembelajaran. Penelitian ini menggunakan tes tertulis pilihan ganda, tujuan tes ini adalah untuk mengetahui pemahaman siswa setelah mengikuti pembelajaran.

b. Memilih media pembelajaran yang sesuai dengan materi dan karakteristik siswa yang mampu menunjang terlaksananya pembelajaran.

c. Pemilihan bentuk penyajian pembelajaran disesuaikan dengan media pembelajaran yang digunakan.

d. Desain perangkat pembelajaran Pada penelitian ini produk yang dikembangkan terdiri dari silabus, rencana pelaksanaan pembelajaran (RPP), buku ajar siswa (BAS), dan lembar kerja siswa (LKS).

3. Tahap Pengembangan (Develop) Menurut Thiagarajan dalam Hanum (2015: 26) mendefinisikan pada tahap pengembangan (Develop) ini tebagi menjadi dua kegiatan yaitu: expert appraisal dan developmental testing. Expert appraisal merupakan teknik untuk menilai kelayakan rancangan produk. 
Teknik pengumpulan data yang digunakan dalam penelitian ini adalah Observasi, wawancara, kuesioner atau angket, dokumentas dan tes. Analisis data yang dilakukan yaitu:

1. Analisis kelayakan perangkat pembelajaran.

Teknik analisis kelayakan perangkat pembelajaran yang meliputi Silabus, rencana pelaksanaan pembelajaran (RPP), buku ajar siswa (BAS), lembar kerja siswa (LKS) ditinjau dari isi, konstruk dan bahasa. Untuk mendeskripsikan kualitas perangkat pembelajaran dapat dihitung dengan menggunakan rumus menurut Apriyanti (2017:27) sebagai berikut:

Skor

$$
\text { Penilaian }=\frac{\text { Jumlah } \text { Skor } \text { Pada Intrumen }}{\text { Jumlah } \text { Nilai } \text { } \text { otal } \text { Skor }} \times 4
$$

\section{Analisis respon siswa}

Respon siswa adalah penerimaan, tanggapan siswa yang diberikan pada saat telah menggunakan perangkat pembelajaran. Respon siswa dapat dihitung dengan menggunakan rumus menurut Indiani (2015: 52) sebagai berikut:

$$
\text { Rerata skor }=\frac{\text { Skor total }}{\text { Banyak butir pertanyaan }}
$$

Berdasarkan perhitungan tersebut, untuk menentukan kriteria respon siswa terhadap perangkat pembelajaran dapat dilihat pada tabel 1 sebagai berikut:

Tabel 1 Modifikasi Skor Respon Siswa

\begin{tabular}{cccc}
\hline No & Skor & Interval Skor & Kriteria \\
\hline 1. & 4 & $3,50-4,00$ & Sangat Baik \\
2. & 3 & $2,50-3,40$ & Baik \\
3. & 2 & $1,50-2,40$ & Cukup Baik \\
4. & 1 & $1,00-1,40$ & Kurang Baik \\
\hline
\end{tabular}

Suprapti (2015: 356)

3. Analisis keterlaksanaan pembelajaran, Analisis aktivitas siswa, nilai karakter siswa

Data yang diperoleh dari keterlaksanaan pembelajaran, aktivitas siswa, dan nilai karakter siswa dianalisis secara deskriptif kuantitatif. Berdasarkan skor yang telah didapat, hasil analisis tersebut dijabarkan untuk memperoleh kualitas angka-angka., dapat dihitung dengan menggunakan rumus menurut Supartin (2013: 23) sebagai berikut:

$$
\text { Nilai }=\frac{\text { Jumlah } \text { Skor }}{\text { Jumlah skor maxsimal }} \times 100 \%
$$

Berdasarkan perhitungan tersebut, untuk menentukan kriteria, dapat dilihat pada tabel 2 sebagai berikut:

Tabel 2 Modifikasi nilai Keterlaksanaan Pembelajaran

\begin{tabular}{ccc}
\hline No & $\begin{array}{c}\text { Interval Nilai } \\
\text { Persentase }\end{array}$ & Kriteria \\
\hline 1. & $p \geq 85 \%$ & Sangat baik \\
2. & $70 \% \leq p<85 \%$ & Baik \\
3. & $50 \% \leq p<70 \%$ & Cukup baik \\
4. & $p \leq 50 \%$ & Kurang baik \\
\hline Yamasari dalam Yuliana ( 2017: 64)
\end{tabular}

4. Analisis hasil belajar siswa

Teknik analisis hasil belajar merupakan pengamatan yang dilakukan oleh peneliti untuk mengukur pemahaman siswa setelah mengikuti pembelajaran dengan menggunakan perangkat pembelajaran. Perhitungan dapat dilakukan dengan rumus menurut Sanjaya (2016: 66) sebagai berikut: 
Ketuntasan Belajar (\%) $=\frac{\text { Banyak Siswa Tuntas }}{\text { Banyak Siswa Total }}$ X 100\%

Berdasarkan perhitungan tersebut, untuk menentukan kriteria tes hasil belajar siswa dapat dilihat pada tabel 3 sebagai berikut:

Tabel 3 Modifikasi Skor Kriteria Ketuntasan

\begin{tabular}{ccc}
\hline No & $\begin{array}{c}\text { Interval skor } \\
\text { Persentase }\end{array}$ & Kriteria \\
\hline 1. & $80-100 \%$ & Sangat baik \\
2. & $70-79 \%$ & Baik \\
3. & $60-69 \%$ & Cukup baik \\
4. & $0-59 \%$ & Kurang baik \\
\hline \multicolumn{2}{c}{ Widoyoko dalam Indiani (2015: 54) }
\end{tabular}

\section{HASIL PENELITIAN DAN PEMBAHASAN}

\section{Kelayakan perangkat pembelajaran}

Validasi isi, konstruk dan bahasa melalui tim ahli dalam bidang-bidang tersebut. Validasi ahli isi untuk silabus dan rencana pelaksanaan pembelajaran (RPP) memperoleh skor rata-rata sebesar 4 dan berada pada kriteria sangat baik. berdasarkan skor perolehan, silabus dan rencana pelaksanaan pembelajaran (RPP) sesuai dengan perangkat pembalajaran IPA berkarakter berbasis integrasi model pembelajaran problem based learning dan keterampilan proses sains yang terdiri atas mengamati, mengkomunikasikan, mengelompokkan dan menyimpulkan serta langkah-langkah model pembelajaran sesuai dengan problem based learning, kesesuaian nilai karakter yang diamati yaitu rasa ingin tahu dan tanggung jawab, kesesuaian kompetensi dasar, kesesuaian indikator dan tujuan pembelajaran dengan memperoleh nilai 4 kriteria sangat baik, tujuan sesuai dengan aspek Audience, Behaviour, Condition, Degree $(A B C D)$.

Validasi isi buku ajar siswa (BAS) diperoleh nilai skor rata-rata 4 kriteria sangat baik. Hal ini menunjukkan bahwa format buku ajar siswa menambah daya tarik siswa, mendorong siswa untuk belajar, menumbuhkan rasa ingin tahu siswa dan tanggung jawab siswa, memberi tantangan pada siswa untuk memecahkan masalah sesuai dengan perangkat pembelajaran IPA berkarakter berbasis integrasi model pembelajaran problem based learning dan keterampilan proses sains yang terdiri dari mengamati,mengkomunikasikan, mengelompokkan, dan menyimpulkan. Berdasarkan pernyataan tersebut sejalan dengan pendapat Hanifah (2014:108) yang menyatakan bahwa buku ajar yang baik adalah buku ajar yang mampu menunjang proses pembelajaran dan daya tarik siswa untuk belajar. Hasil validasi ahli isi untuk buku ajar siswa (BAS) memperoleh skor rata-rata sebesar 4 kriteria sangat baik.

Hasil validasi ahli isi lembar kerja siswa (LKS) diperoleh nilai skor rata-rata 3,87 kriteria sangat baik. Hal ini menunjukkan bahwa perangkat pembelajaran lembar kerja siswa (LKS) memberikan tantangan kepada siswa untuk mencari tahu tentang informasi terkait percobaan yang disajikan sesuai dengan perangkat pembelajaran IPA berkarakter berbasis integrasi model pembelajaran problem based learning dan keterampilan proses sains mengamati,mengkomunikasikan, mengelompokkan dan menyimpulkan. Sriyono dalam Ade (2014: 8) mendefinisikan bahwa lembar kerja siswa (LKS) yang baik memuat tugas yang menantang untuk diselesaikan oleh siswa. Hasil validasi ahli isi lembar kerja siswa (LKS) memperoleh skor rata-rata sebesar 3,87 kriteria sangat baik.

Hasil validasi oleh ahli konstruk untuk silabus dan rencana pelaksanaan pembelajaran (RPP) diperoleh nilai skor rata-rata 4 kriteria sangat baik. Hal ini menunjukkan bahwa perangkat pembelajaran terdapat satuan pendidikan, kelas, semester, mata pelajaran, alokasi waktu, menuliskan standar kompetensi, kompetensi dasar, indikator, tujuan pembelajaran sesuai dengan indikator, perumusan tujuan sesuai dengan aspek Audience, Behaviour, Condition, Degree (ABCD), menampilkan kegiatan 
pendahuluan, inti, dan penutup dengan jelas, kegiatan pembelajaran sesuai dengan sistematika atau keruntutan materi, alokasi waktu sesuai dengan kegiatan pendahuluan, inti, dan penutup dinyatakan dengan jelas, penggunaan buku ajar siswa (BAS) dan lembar kerja siswa (LKS) diskenariokan dalam rencana pelaksanaan pembelajaran (RPP), bentuk, teknik dan instrumen penilaian sesuai dengan indikator pencapaian kompetensi, susunan kalimat benar dan lengkap, menggunakan kosa kata yang lengkap dan benar, kalimat soal pada silabus dan rencana pelaksanaan pembelajaran (RPP) tidak menimbulkan penafsiran ganda, rumusan permasalahan menggunakan kalimat tanya dan kesederhanaan struktur kalimat.

Trianto dalam Melati (2016: 54) merumuskan rencana pelaksanaan pembelajaran (RPP) yang baik merangkum identitas mata pelajaran, standar kompetensi (SK), kompetensi dasar (KD), indikator pencapaian kompetensi, tujuan pembelajaran, materi ajar, alokasi waktu, pendekatan atau model pembelajaran, langkah-langkah dalam pembelajaran, penilaian hasil belajar, dan sumber belajar. Pada penyusunan rencana pelaksanaan pembelajaran (RPP) terlebih dahulu menentukan rencana pelaksanaan pembelajaran (RPP) dan jumlah pertemuan dalam pembelajaran dibuat berdasarkan standar kompetensi (SK), kompetensi dasar (KD), indikator, dan tujuan pembelajaran yang telah ditentukan. Hasil validasi ahli konstruk silabus dan rencana pelaksanaan pembelajaran (RPP) memperoleh rerata skor sebesar 4 kriteria sangat baik.

Berikutnya validasi konstruk buku ajar siswa (BAS) mendapatkan rerata skor 4 kriteria sangat baik dan layak. Hal ini menunjukkan bahwa buku ajar siswa (BAS). Menunjukkan bahwa susunan kalimat benar dan lengkap, menggunakan kosa kata tepat dan benar, rumusan pada permasalahan menggunakan kalimat tanya, menggunakan gambar yang jelas, mendorong aktivitas siswa dan desain buku menambahkan daya tarik siswa. Berdasarkan pernyataan tersebut sejalan dengan ungkapan Sudirman dalam Wirjawan (2014:97) buku ajar siswa yang baik apabila mampu mendorong aktivitas siswa dan daya tarik siswa dalam pembelajaran. Hasil validasi ahli konstruk untuk buku ajar siswa (BAS) memperoleh skor rata-rata sebesar 4 kriteria sangat baik.

Validasi ahli konstruk pada lembar kerja siswa (LKS) mendapatkan rerata skor 4 kriteria sangat baik. Berdasarkan skor tersebut, kegiatan dalam perangkat pembelajaran yang terdapat perangkat pembelajaran lembar kerja siswa (LKS) sesuai dengan tujuan (indikator pencapaian kompetensi), prosedur urutan kerja, manfaat terhadap pembelajaran, susunan kalimat benar dan lengkap, penggunaan kosa kata tepat dan benar, petunjuk mengerjakan percobaan dinyatakan dengan jelas, mendorong siswa untuk aktif melakukan percobaan, mendorong aktivitas siswa dan desain menumbuhkan daya tarik siswa dalam pembelajaran. Hal tersebut sejalan dengan Sriyono dalam Ade (2014: 8) mendefinisikan bahwa lembar kerja siswa (LKS) adalah salah satu bentuk program yang berlandaskan atas tugas yang harus diselesaikan dan memiliki peran sebagai alat untuk mengalihkan pengetahuan serta keterampilan sehingga berupaya menumbuhkan minat siswa dalam mengikuti proses pembelajaran. Hasil validasi ahli konstruk untuk lembar kerja siswa secara keseluruhan memperoleh rerata skor sebesar 4 kriteria sangat baik.

Berdasarkan Validasi ahli Bahasa, silabus dan rencana pelaksanaan pembelajaran (RPP) mendapatkan rerata skor 3,71 kriteria sangat baik. Hal ini menunjukkan ketepatan tata bahasa yang terdapat pada perangkat pembelajaran silabus dan rencana pelaksanaan pembelajaran (RPP), perolehan skor 4 menyatakan bahwa bahasa yang digunakan sesuai dengan EYD, bahasa mudah dipahami, penggunaan bahasa tidak menimbulkan penafsiran ganda, kesederhanaan struktur kalimat dan penggunaan kalimat jelas.

Berdasarkan Permendikbud Nomor 65 Tahun 2013, rencana pelaksanaan pembelajaran (RPP) merupakan penjabaran dari silabus untuk mengarahkan kegiatan belajar siswa dalam upaya mencapai kompetensi dasar. Guru yang melaksanakan kegiatan pembelajaran dikelas dituntut untuk menyusun rencana pelaksanaan pembelajaran (RPP) secara lengkap, sehingga pembelajaran dapat berlangsung secara interaktif, inspiratif, menyenangkan, menantang, memotivasi siswa untuk berpartisipasi aktif serta memerhatikan kaida bahasa yang digunakan sehingga perangakat pembelajaran mampu menari daya minat siswa. Adapun komentar ahli bahasa yaitu 
perbaiki ejaan dan tanda baca. Hasil validasi ahli bahasa terhadap perangkat pembelajaran silabus dan rencana pelaksanaan pembelajaran (RPP) secara keseluruhan adalah 3,71 kriteria sangat baik.

Validasi ahli bahasa buku ajar siswa (BAS) diperoleh nilai skor rata-rata 3,75 kriteria sangat baik. Hal ini menunjukkan bahwa perangkat pembelajaran buku ajar siswa (BAS) memberikan pesan atau informasi kepada siswa dengan menggunakan tata bahasa yang benar. Perolehan skor 4 menyatakan bahwa bahasa yang digunakan mudah dipahami oleh siswa, penggunaan bahasa tidak menimbulkan penafsiran ganda, kesederhanaan struktur kalimat, kalimat yang digunakan jelas.

Berkaitan dengan penjelasan tersebut sejalan dengan ungkapan oleh sudirman dalam Wirjawan (2014: 97) yang menyatakan bahwa buku ajar yang disusun seharusnya menggunakan sesuai dengan EYD yaitu penggunaan ejaan, istilah, dan struktur kalimat yang tepat. Hasil validasi ahli bahasa untuk buku ajar siswa (BAS) memperoleh skor rata-rata sebesar 3,75 dengan kriteria sangat baik.

Berikutnya validasi ahli bahasa untuk perangkat pembelajaran lembar kerja siswa (LKS) diperoleh rerata skor 3,88 kriteria sangat baik. Hal ini menunjukkan bahwa bahasa yang digunakan dalam perangkat pembelajaran lembar kerja siswa (LKS) sesuai dengan kaidah bahasa Indonesia yang baku, perolehan skor 4 menyatakan bahwa kebenaran tata bahasa, bahasa mudah dipahami, penggunaan bahasa tidak menimbulkan menafsirkan ganda, kesederhanaan struktur kalimat, bahasa yang digunakan sesuai dengan karateristik siswa, kalimat yang digunakan jelas dan kejelasan petunjuk melakukan percobaan. Berdasarkan pernyataan tersebut sejalan dengan ungkapan oleh Widjajanti dalam Sugianto (2013: 6) penyajian lembar kerja siswa (LKS) meliputi penyampaian materi secara ringkas dan jelas sesuai dengan kaidah bahasa indonesia, kemudian terdapat kegiatan yang melibatkan siswa secara aktif.

Berdasarkan hasil analisis perangkat pembelajaran tersebut dapat disimpulkan bahwa perangkat pembelajaran IPA berkarakter berbasis integrasi model pembelajaran problem based learning dan keterampilan proses sains di kelas V-C ditinjau dari hasil validasi isi, konstruk dan bahasa secara keseluruhan mendapatkan rerata skor 3,91 dengan kriteria sangat layak.

Respon siswa terhadap perangkat pembelajaran yang dikembangkan diberikan kepada siswa setelah mengikuti kegiatan pembelajaran memperoleh skor rata-rata keseluruhan 3,74 dengan kriteria sangat baik. Hal ini juga diungkapkan oleh Ma'sum (2015: 10) menyatakan bahwa ketertarikan siswa terhadap komponen perangkat pembelajaran yang dikembangkan menunjukkan bahwa siswa lebih mudah untuk memahami perangkat pembelajaran dikembangkan.

Keterlaksanaan pembelajaran yang dilakukan mendapatkan rerata skor keseluruhan keterlaksanaan pembelajaran sebesar 3,97 dengan persentase 99,25\% kriteria sangat baik. Hal ini sejalan dengan ungkapan Sugiantara (2013: 9) yang menjelaskan bahwa keterlaksanaan pembelajaran dapat terlaksana jika mudah dan dapat dilaksanakan oleh guru maupun siswa. Yamsari dalam Yuliana (2017: 64) menyatakan bahwa keterlaksanaan pembelajaran dikatakan sangat baik jika memiliki persentase $p \geq 85 \%$.

Aktivitas siswa dalam kegiatan pembelajaran yang dilakukan, diperoleh kriteria sangat baik, skor rata-rata 3,5 dengan persentase $87,5 \%$ kriteria sangat baik. Sukardi dalam Nurhasanah (2015: 324) menjelaskan bahwa aktivitas siswa termasuk dalam kriteria sangat baik jika memiliki persentase $\mathrm{Pa} \geq 84 \%$. Keterampilan proses sains dapat membuat siswa lebih memperhatikan materi pembelajaran yang telah diberikan (Prabowo, 2015)

Nilai Karakter siswa yang ditampilkan oleh siswa terhadap perangkat pembelajaran yang digunakan sangat baik. perolehan skor rata-rata keseluruhan pengamatan nilai karakter sebesar 3,7 dengan persentase 92,5\% kriteria sangat baik. Hal ini sesuai dengan ungkapan Asrial (2016: 11) mendefinisikan bahwa karakter pada siswa dikatakan sangat baik jika memiliki persentase $80<x \leq 100 \%$.

Pada kegiatan akhir pembelajaran, siswa mengerjakan soal evaluasi dengan tujuan mengukur pemahaman siswa terhadap pembelajaran dengan perangkat pembelajaran yang telah dikembangkan. Keterampilan proses dapat meningkatkan 
prestasi siswa dan meningkatkan kualitas proses pembelajaran (Sulaiman, 2009). Hasil belajar siswa secara keseluruhan menunjukkan persentase ketuntasan siswa mencapai $88 \%$. (sangat baik). Keterampilan proses sains bukan hanya keterampilan menggunakan alat, tetapi keterampilan berpikir dengan menggunakan metode ilmiah untuk memfasilitasi siswa agar dapat memahami konsep ilmiah (Ratnasari, 2017). Selain itu pemikiran analitis terkait dengan keterampilan proses sains dapat digunakan siswa untuk memecahkan masalah yang kompleks dan tidak terstruktur (Irwanto, 2017). Dengan pemahaman konsep dan kemampuan analisis yang yang baik, membuat ketuntan belajar mencapai ketuntasan klasikal di kelas.

Penilaian proses dan hasil belajar pada kegiatan pembelajaran menunjukkan bahwa guru memantau kemajuan belajar siswa selama proses pembelajaran dan melakukan penilaian sesuai dengan kompetensi (tujuan) (Azhari, 2018). Pembelajaran dengan menggunakan pendekatan keterampilan proses sains dapat meningkatkan hasil belajar siswa, hal ini senada dengan pernyataan Alamsyah, dkk (2018) yang menyatakan bahwa penggunaan keterampilan proses sains dapat meningkatkah hasil belajar siswa kelas V-B SDN 045 Tarakan. Azhari (2018) juga mengembangkan perangkat pebelajaran berbasis cooperatif script dan keterampilan proses sains. Hasil yang diperoleh yaitu perangkat pembelajaran yang dikembangkan mendapatkan rerata skor 3.31 dengan kriteria sangat baik dan respon siswa mendapatkan kriteria sangat baik. Dewi (2018) mengembangkan modul IPA berbasis keterampilan proses sains untuk mengembangkan karakter siswa dan mendapatkan kategori layak. Hal senada juga diungkapkan Anggraini (2016) yang menyatakan bahwa siswa setuju dengan penerapan pendekatan keterampilan proses membuat siswa mudah memahami materi.

\section{KESIMPULAN}

Berdasarkan uji validasi perangkat pembelajaran IPA berkarakter berbasis integrasi model pembelajaran problem based learning dan keterampilan proses sains secara keseluruhan diperoleh skor rata-rata 3,91 kriteria sangat layak. Hasil validasi yang dilakukan berdasarkan ujivalidasi isi, konstruk dan bahasa secara keseluruhan yaitu silabus, dan RPP mendapatkan skor 3,9 (sangat baik), buku ajar siswa (BAS) mendapat skor 3,92 (sangat baik) dan Lembar kerja siswa (LKS) 3,92 kriteria sangat baik. Respon siswa terhadap perangkat pembelajaran IPA berkarakter berbasis integrasi model pembelajaran problem based learning dan keterampilan proses sains diperoleh skor rata-rata 3,74 dengan kriteria sangat baik.

\section{SARAN}

Saran yang dapat diberikan adalah sebagai berikut:

1. Perangkat pembelajaran IPA berkarakter berbasis integrasi model pembelajaran problem based learning dan keterampilan proses sains pada materi perubahan sifat benda yang telah dikembangkan diharapkan dapat digunakan di sekolah yang memiliki karakteristik yang sama.

2. Perangkat pembelajaran yang telah dikembangkan memiliki kelayakan dari segi isi, bahasa dan konstruk yang sangat baik. Oleh karena itu, bagi peneliti yang lain dapat melakukan pengembangan perangkat pembelajaran serupa yang sesuai dengan karakteristik materi dan model yang digunakan.

\section{DAFTAR PUSTAKA}

Apriyanti Yeni. 2017. Pengembangan Perangkat Pembelajaran sFlipped Classroom Pada Materi Getaran Harmonis. Bandar Lampung: Universitas Lampung.

Alamsyah, S., Annisa, M., \& Kusnadi, D. (2018). Penerapan Pendekatan Keterampilan Proses Sains Untuk Meningkatkan Hasil Belajar Ipa Siswa Kelas VB SDN 045 Tarakan. 
Anggraini, R., Wahyuni, S., \& Lesmono, A. D. (2016). Pengembangan lembar kerja siswa (LKS) berbasis keterampilan proses di SMAN 4 Jember. Jurnal Pembelajaran Fisika, $4(4), 350-365$.

Annisa, M., Yulinda, R., \& Mas' an Al Wahid, S. (2017, May). The Analysis of Science Process Skills on Natural Science Questions at Elementary Schools in Tarakan. In 5th SEA-DR (South East Asia Development Research) International Conference 2017 (SEADRIC 2017). Atlantis Press.

Annisa, M., Yulinda, R., \& Kartini, K. (2018). Identifying the Misconceptions of Natural Science (IPA) Using CRI (Certanty of Response Index) at the Primary School Students in Tarakan. JIPF (Jurnal IImu Pendidikan Fisika), 2(2), 54-59.

Asrial, dkk. 2016. Pengembangan Lembar Kegiatan Siswa Berbasis Karakter Pada Mata Pelajaran Kimia SMA. Jambi: Universitas Jambi

Azhari, S. A., Annisa, Muhsinah., \& Kartini, K. (2018). Pengembangan Perangkat Pembelajaran IPA Integrasi Cooperative Script dan Keterampilan Proses Sains Di Kelas IV-a SDN 049 Tarakan.

Bhakti, Y. B., Astuti, D., \& Agustina, I. (2018). The influence process of science skill and motivation learning with creativity learn. Journal of Education and Learning, 12(1), 30-35.

Dewi, E. M., Annisa, M., \& Kunadi, D. (2018). PENGEMBANGAN MODUL IPA BERBASIS KETERAMPILAN PROSES SAINS DALAM MENGEMBANGKAN KARAKTER PADA SISWA KELAS VA SDN 007 TARAKAN.

Haniah, F., Annisa, M., \& Kartini, K. (2018). Pengembangan Instrumen Tes Berbasis Keterampilan Proses Sains Pada Materi Benda Dan Sifatnya Kelas V SDN 010 Tarakan. Widyagogik: Jurnal Pendidikan dan Pembelajaran Sekolah Dasar, 6(1), 2946.

Hanum faridah dan Lia Prastyawati. 2015. Pengembangan Model Pembelajaran Pendidikan Multikultural Berbasis Proyek di SMA. Yogyakarta: Universitas Negeri Yogyakarta.

Indiani Venti. 2015. Pengembanagan Pembelajaran Berbasis Contextual Teaching and Learning (CTL) Pada Materi Barisan dan Deret Untuk Siswa SMA Kelas $X$. Yogyakarta: Universitas Negeri Yogyakarta

Irwanto, Rohaeti, E., Widjajanti, E., \& Suyanta. (2017, August). Students' science process skill and analytical thinking ability in chemistry learning. In AIP Conference Proceedings (Vol. 1868, No. 1, p. 030001). AIP Publishing LLC.

Listiyani, Indriana Mei. 2012. Pembangan Komik Sebagai Media Pembelajaran Akuntansi Pada Kompetensi Dasr Persamaan Dasar Akutansi Untuk Siswa SMA Kelas XI. Yogyakarta: Univesitas Negeri Yogyakarta

Nurhasanah, dkk. 2015. Pengembangan Perangkat Pembelajaran Matematika Dengan Pendekatan Kooperatif Learning Together dan Berorientasi Pembentukan Karakter Siswa. Jember: Universitas Jember

Prabowo, S. A. (2015). The effectiveness of scientific based learning towards science process skill mastery of PGSD students. Jurnal Pendidikan IPA Indonesia, 4(1), 1519. 
Ratnasari, D., Sukarmin, S., Suparmi, S., \& Aminah, N. S. (2017, September). Students' conception on heat and temperature toward science process skill. In Journal of Physics: Conference Series (Vol. 895, No. 1, p. 012044). IOP Publishing.

Sanjaya, Tanri Mega. 2016. Pengembangan Perangkat Pembelajaran Geometri SMP Yang Menunjang Pendidikan Karakter. Pundong: Perguruan Tinggi La Tansa Mashiro Pundong

Saputri, F. E., Annisa, M., \& Kusnandi, D. (2018). PENGEMBANGAN MEDIA PEMBELAJARAN IPA MENGGUNAKAN AUGMENTED REALITY (AR) BERBASIS ANDROID PADA SISWA KELAS III SDN 015 TARAKAN. Widyagogik: Jurnal Pendidikan dan Pembelajaran Sekolah Dasar, 6(1), 57-72.

Serevina, V. (2018). Development of E-Module Based on Problem Based Learning (PBL) on Heat and Temperature to Improve Student's Science Process Skill. Turkish Online Journal of Educational Technology-TOJET, 17(3), 26-36.

Sulaiman, T., Hassan, A., Levinas, R. B. E., \& Freire, P. (2009). Readiness of year 1 students to learn science process skills in English: A Malaysian experience. International Journal of Instruction, 2(1).

Sulistyorini, dkk. 2016. Pengembangan Perangkat Pembelajaran IPA Model Guided Inquiry Untuk Melatihkan Keterampilan Proses Sains dan Menigkatkan Hasil Belajar Siswa SMP. Surabaya: Universitas Negeri Surabaya.

Suprapti. 2015. Meningkatkan Kualitas Pembelajaran Matematika pada Topik Dimensi Tiga Melalui Pembelajaran Kooperatif Tipe STAD Dengan Pendekatan Saintifik Realistik Siswa Kelas X SMA. Makassar: SMA Negeri 16 Makassar.

Supartin, dkk. 2013. Pengembangan Model Pembelajaran Sains Melalui Pendekatan Pakem Yang Berintegrasi Dengan endidikan Berbasis Karakter Pada Siswa di SMP. Gorontalo: Universitas Negeri Gorontalo.

Yuliana. 2010. Pentingnya Pendidikan Karakter Bangsa Guna Merevitalisasi Ketahanan Bangsa. Denpasar: Universitas Hindu Indonesia Denpasar. 